\title{
DIDACTIC OPPORTUNITIES OF INFORMATION-COMMUNICATION TECHNOLOGIES IN THE CONTROL OF PHYSICAL EDUCATION
}

\author{
Viktor Koryahin $^{\mathrm{ABCD}}$, Zinovy Mykytyuk ${ }^{\mathrm{ABCD}}$, Oksana Blavt ${ }^{\mathrm{ABCD}}$, Liubov Dolnikova ${ }^{\mathrm{ABCD}}$, \\ Volodymyr Stadnyk ${ }^{\mathrm{ABCD}}$ \\ Lviv Polytechnic National University \\ Authors' Contribution: A - Study design; B - Data collection; C - Statistical analysis; D - Manuscript Preparation; E - Funds Collection
}

Corresponding Author: Oksana Blavt, e-mail: oksanablavt@ukr.net

Accepted for Publication: June 20, 2020

Published: June 25, 2020

DOI: $10.17309 / \mathrm{tmfv.2020.2.06}$

\begin{abstract}
The study objective is to justify and implement information and communication technologies in the test control of the development level of the frequency of movements, as a manifestation of speed qualities in the process of physical education.

Materials and Methods. To solve the research tasks, the study used the methods of comparing and contrasting, analysis, synthesis, abstraction, formalization and technical modeling.

Results. An electronic device for the exercise controlling the movement frequency of the hands to evaluate speed qualities was developed for the research purpose. The device is designed on the basis of capacitive type proximity sensors. The signal received by the sensors is processed in the microcontroller unit during the test and transmitted to the personal computer via the communication interface. On a personal computer, using the developed software, they control the time of completion of the test task.

Conclusions. The developed information and communication technologies based on electronic monitoring device embodies a new approach to addressing the challenge of improving the performance of speed control in physical education by ensuring that objective and reliable test data are obtained promptly.

Key words: physical education, control, testing, information and communication technologies, speed and power
\end{abstract} abilities, sensor device.

\section{Introduction}

Problem statement. Effective functioning of control in physical education is considered as a key factor in solving its goals and objectives (Bassett, 2000; Koryahin, Blavt, \& Ponomaryov, 2019). Therefore, methodological support of the control process is of particular importance, since its effectiveness depends on the quality, timeliness and content of the information received (Lauber, \& Keller, 2014). In this context, the introduction of new innovative tendencies, which at the present stage of scientific and technological progress, are characterized by strong evolutionary changes in all fields of knowledge, is of particular relevance (Gonzalo-Skok, Sánchez-Sabaté, Izquierdo-Lupón, \& Sáez de Villarreal, 2019; Koryahin, \& Blavt, 2018).

The importance of finding and implementing innovative approaches to controlling physical education and improving the technological foundations of this process is dictated by time (Koryahin, Mukan, Blavt, \& Virt, 2019). In the conditions of globalization, rapid spread and intensive introduc-

(C) Viktor Koryahin, Zinovy Mykytyuk, Oksana Blavt, Liubov Dolnikova, Volodymyr Stadnyk, 2020. tion of information and communication technologies (ICT), using the potential of modernization in the modern scientific space, it is possible to significantly increase the informatization of physical training through the use of ICT (Strohrmann, Harms, Kappeler-Setz, \& Troster, 2012).

Considering the possibility of introducing new controls to improve the efficiency of physical education, to bring this process closer to world standards, to ensure high quality of physical training, to explore the possibilities of implementing productive ideas of integrating ICT in the control of physical education, is updating further scientific research in this direction.

Analysis of recent research and publications. The problem of ensuring the efficiency of physical education is constantly analyzed by scientists, experts, and specialists of the field. The works (Alfrey, \& Gard, 2014; Di Tore, Schiavo, D'isanto, 2016) substantiate the basic reasons for the imperfection of the existing system of control in physical education, indicate the testing methodology (Jrgensen, Andersen, Froberg, Maeder, Smith, \& Aadahl, 2009; Koryagin, \& Blavt, 2019). Its disadvantages are pointed out, in particular: its dependence on a human factor (Geoffrey, Power, Handrigan, Basset, 2012; Koryahin, Blavt, \& Ponomaryov, 2019); low level of reliabil- 
ity and consistency of test methods (Alfrey, \& Gard, 2014; Bassett, 2000; Gonzalo-Skok, Tous-Fajardo, Suarez-Arrones, Arjol-Serrano, Casajus, \& Mendez-Villanueva, 2015); ensuring the reliability of information (Matiegka, 1991; Silverman, Keating, \& Phillips, 2008); lack of a single network of observations (Reiman, \& Manske, 2009); obsolete technical and methodological support for observations (Magill, 2007; Koryahin, Mukan, Blavt, \& Virt, 2019).

In this aspect, the increased attention of specialists is now being paid to the problem of physical education development based on innovations. The successful implementation of this process is believed to ensure the full utilization of the scientific potential of the latest information and communication technologies (ICT) (Capobianco, Almuklass, \& Enoka, 2018; Chow, Chung, Ma, Macfarlane, \& Shirley, 2017; Gonzalo-Skok, Sánchez-Sabaté, Izquierdo-Lupón, \& Sáez de Villarreal, 2019), increases the efficiency of learning (Estivalet, \& Springer, 2009; Kok, Komen, Capelleveen, \& Kamp, 2020; Strohrmann, Harms, Kappeler-Setz, \& Troster, 2012).

The scientific advances of intelligence on the modernization of control procedures are quite widespread (Alfrey, \& Gard, 2014; Clarys, \& Cabri, 1993; Reiman, \& Manske, 2009). It is determined (Preatoni, Hamill, Harrison, Hayes, Van Emmerik, Wilson, \& Rodano, 2013), that ensuring the effectiveness of this process through the modernization of the means of implementation of control is, of course, an important and urgent task. A number of studies have been devoted to the use of innovative ICT in the practice of physical education (Chow, Chung, Ma, Macfarlane, \& Shirley, 2017; Estivalet, \& Springer, 2009), its didactic and methodological aspects (Koryahin, \& Blavt, 2018; Preatoni, Hamill, Harrison, Hayes, Van Emmerik, Wilson, \& Rodano, 2013).

The works justify the indisputable need to introduce innovations, fundamentally new approaches to the implementation of control in physical education (Lauber, \& Keller, 2014; Silverman, Keating, Phillips, 2008). In recent years, the topic of electronic methods and means of test measurements has been consistently among the scientific priorities (Haake, 1996; Hotra, Mahlovanyy, Mykytyuk, Ivakh, \& Politanskyi, 2019). The use of ICT in test control of physical education is regarded as one of the resources that have a significant impact on the quality of testing procedures, which implies a new level of quality and effectiveness (Estivalet, \& Springer, 2009; Strohrmann, Harms, Kappeler-Setz, \& Troster, 2012). The integration of ICT creates the prerequisites for a radical renewal of both the contentbased and technological aspects of control, which is manifested in the enrichment of the system of didactic techniques and tools (Koryahin, Mukan, Blavt, \& Virt, 2019).

However, despite the fact that the topic of innovation in the current scientific literature is quite well discussed, there is limited research on the modernization of control procedures in physical education based on the introduction of ICT.

The purpose of the article is to justify and implement ICT in the test control of the level of development of the frequency of movements, as a manifestation of speed qualities in the process of physical education.

\section{Materials and methods}

The methodological framework based on research has been formed based on the bases of the correlation of general to specific, the unity of theory and practice, the provisions of regularities on processes. The research strategy is focused on the integration of information resources of modern ICTs to ensure the effectiveness of control in the process of physical education. The pilot study aimed to eliminate a number of problematic factors and to ensure promptness, objectivity of ICT testing.

The authors highlight the literature review and methods used in the study theory: synthesis, induction and deduction, correlation, comparison and critical reflection, logical method, structural and systemic method, method of systematization and generalization.

To solve the research tasks used the methods of technical modeling. A method of modeling based on a comprehensive approach (synthesis of analytical and simulation modeling) was proposed, which allowed us to gain new knowledge about the object of scientific research. Technical simulation was used to create a device to be studied: the use of technical means gave the simulation an experimental character. This method provided the definition of the properties of the modeled detailing of the model and the level of detail of its representation by means of images. A comprehensive approach allowed to capture a qualitatively new presentation of the research results.

\section{Results}

First of all, in order to conduct research in a certain direction, we consider it necessary to specify that we are investing in the concept of "speed qualities". We are impressed by the fact that speed qualities are manifested in the ability to perform movements in the shortest possible time. There are so-called elementary and complex forms of expression of speed qualities (Stroot, 2014).

Speed qualities are very specific. There is either no dependency between the various forms of their manifestation, or the dependence is quite small. Therefore, in assessing the overall level of development of these qualities, it is necessary to use several speed indicators (Wulf, \& Lewthwaite, 2009).

One of the components of complex speed characteristics is the frequency of unladen movements, which is extremely important in cyclic motions and in the rapid repetition of acyclic motions. Now the assessment of the level of development of the frequency of movements is to perform the specialized test exercise "Test of the speed of the movements of the hands" (Alme, \& Mylvaganam, 2006; Reiman, \& Manske, 2009).

However, in this way, which involves moving the hands and alternately touching the two areas with a comfortable hand with the maximum possible speed and fixing the time of execution of 25 cycles, there is a certain dependence of the subjective assessment of the perception of the evaluator. Subjective perception is the standardization of compliance with the necessary requirements of the test exercise: the correctness of alternately touching the hands, which set visually. At the same time, there is a likelihood of a large error in fixing the time of correctly completed test exercise cycles. All of the above makes it impossible to obtain the relevant test results, so they can not objectively indicate the level of development of speed. The use of such a test exercise does not provide objectively reliable indicators of control over the level of devel- 
opment of speed and because of the average level of reliability and consistency of the test.

An electronic test device for controlling the frequency of hand movements was developed for the purpose of the study. The device is designed on the basis of capacitive-type proximity sensors whose action is based on changing the gap between the plates and their dielectric constant (Bracke, Puers, \& Van Hoof, 2007).

Modern sensor technologies allow you to create sensory devices that are devoid of traditional problems of the past: complexity in development, low reliability and instability in work. The sensors used in this device are extremely reliable, long-life devices. At the same time, these sensors are not susceptible to all kinds of obstacles, characterized by maximum accuracy and reliability. Capacitive sensors are insensitive to changes in temperatures and vibrations and are highly resistant to electromagnetic effects (Hotra, Mahlovanyy, Mykytyuk, Ivakh, \& Politanskyi, 2019; Olmos, Primicia, \& Fernandez Marron, 2007).

In the developed control device, a capacitive control resistor is built into the capacitive sensor to adjust the sensitivity. For this purpose, a unique algorithm is used, which, due to the increased signal strength, reduces the noise interference by eight times compared to the usual one.

Information from capacitive sensors is transmitted not by cable but by light waves, which can vary in intensity, phase, color or geometric distribution in space.

The device is designed on the basis of capacitive-type proximity sensors, which are made on insulating material (fiberglass) in the form of two planar electrodes that can be recognized with up to ten simultaneous touches with jewelry. The sensitive elements of such capacitive sensors are the capacitor matrix with modulated external factors between the electrode electrical capacitance. In the general case, the structure of the capacitive sensors can be divided by the change: the area of he inter-electrode overlap, the inter-electrode distance, the parameters of the inter-electrode dielectric and the influence of environmental objects.

The capacitive sensors are placed in the test disks (Fig. 1), which are located on both sides of the support platform and which, when performing the test, the control subject touches with his hands. Capacitive type sensors are made on insulating material (fiberglass) in the form of two planar electrodes. These electrodes, through a two-wire line, connect to the analog inputs of the microprocessor system (in this case PSoC) to measure the capacitance. The capacitive sensors used to create the device of the capacitive sensors include programmable PSoC systems (CapSense crystal C78C21x34 and C78C24x94) In essence, they are a microcontroller for the joint processing of analog and digital signals. Unlike traditional microcontrollers and their electronic signal conversion systems, the PSoC concept not only provides the ability to program modes of digital and analog system nodes, but also configures the structure of these nodes and their interconnections (CapSenseTM, 2006 Bracke, Puers, \& Van Hoof, 2007).

The capacitive sensor, in addition to the primary converter (User Interface) with which the control subject's hands interacts, contains a signal converter. The structure of the signal converter used includes:

- CapSence Controller with Haptics controller, which measures capacitor array capacities, generates Touch Signal, and hand touch recognition;

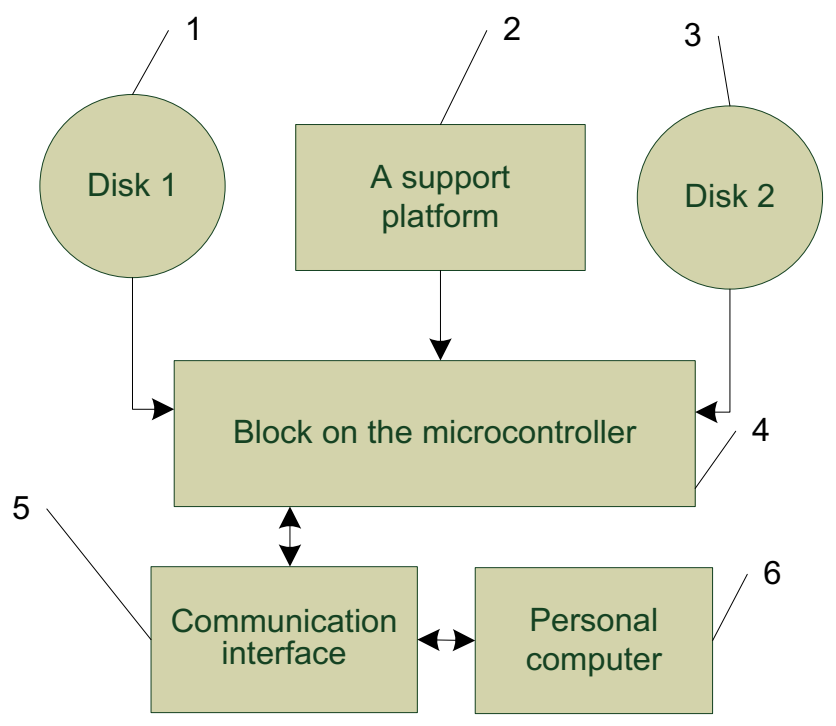

Fig. 1. Structural diagram of the electronic part of the device: 1 - disk 1;2 - a support platform; 3 - disk 2; 4 - block of the microcontroller; 5 - communication interface; 6 - personal computer

- Host Controller, which provides further signal conversion and processing of digital data;

- Amplifier amplifier and Actuator actuator to provide feedback;

- Tactile Feedback Actuation, which improves the accuracy and noise immunity of the measurement process.

After starting the device, the controller determines the value of the capacity in the absence of a hand on test disc 1 and test disc 2 and fixes the optocoupler with the presence of a hand on the support platform and then signals to the personal computer about the readiness to perform the test task.

The number of hand movements performed by the subject of control is calculated by changing the amount of sensor capacity at the time of touching the test disks. One movement is recorded as a sequence of changes in the amount of capacity on the first and second sensors, which are located in the disks. In the absence of one signal (from disk 1 or disk 2), such motion is not counted. Counting is also suspended in the absence of the control entity's hand at the support site. In the event of such situations, the display of the personal computer displays a message about the violation of the methodological requirements for performing the test exercise and indicate its cause. The sensors received in the test disks receive signals promptly to the microcontroller unit, which generates information about the time of 25 cycles of exercise. The results are transmitted via the communication interface to the personal computer. The indication of the end of the test is the lack of change in the capacity of the sensors, which are placed in the disks for 2-3 seconds, or the absence of a signal from the reference pad. The operation of the device is determined by the firmware algorithm and the application software of the personal computer. The information recorded by the electronic control unit is displayed on the digital display and stored in files that are stored on the disk and are available for further processing.

The structure we developed uses a personal computer, but it is also possible to use a mobile telecommunication sys- 
tem that has a high-speed interface subsystem and in which the received signal is processed on a real-time scale. In addition to promptly displaying the results, the device makes it possible to store their values in the internal memory or transfer these values to the control unit for further analysis and visualization.

A way of assessing the level of development of speed attributes, according to which exercise time control is, is that the test subject stands in front of the table, puts the brush of the left (for right-handed) hands on the support platform. Supporting pad $(10 \times 20 \mathrm{~cm})$, located between test disk 1 and test disk 2, placed horizontally on the table (distance between the centers of the disks $-60 \mathrm{~cm}$ ) at an equal distance from each. The right hand is on the left disk. Capacitive-type sensors, which are located under the disks and the support platform, fix with the help of an optocoupler the presence of a hand on the support platform and one of the disks. According to the signal, the test subject alternately touches the disks with the hand brush (right-handed, left-handed), moving the right-hand brush from disc 1 to disc 2 so that it moves over the left hand brush during movement. The task is performed at the maximum possible rate until the number of hand transfers from one disk to another is 25 cycles. The developed electronic control device records the moment of the beginning of the movement of hands and calculates the number of movements by changing the size of the sensor capacity. The signal received by the sensors is processed in the microcontroller unit, which generates information about the time and number of completed test cycles. Further, the signal processed through the communication interface is transmitted by wireless infrared devices to a personal computer. On a personal computer, using the developed software, they control the time of completion of the test task. The results obtained are compared with the evaluation standards and the value of which concludes the level of development of speed qualities. The result is displayed on a personal computer display.

It is known that the maximum effect from the use of ICT is achieved in a complex approach, when different information systems interact (Hotra, Mahlovanyy, Mykytyuk, Ivakh, \& Politanskyi, 2019). This is the approach we use in our development as software infrastructure. Software has been developed to automate the process of maintaining registration information and performing control and automated information processing. The function of this assurance is to filter

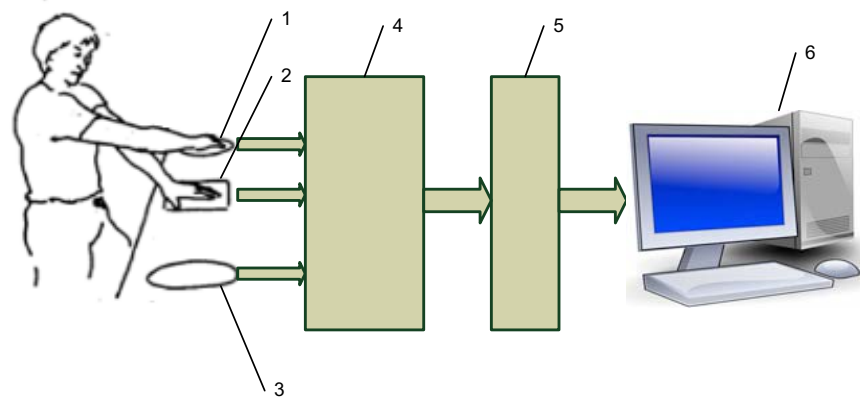

Fig. 2. Block diagram of a method of controlling the level of development of speed qualities: 1 - disk $1 ; 2$ - a support platform; 3 - disk 2; 4 - block of the microcontroller; 5 - communication interface; 6 - personal computer

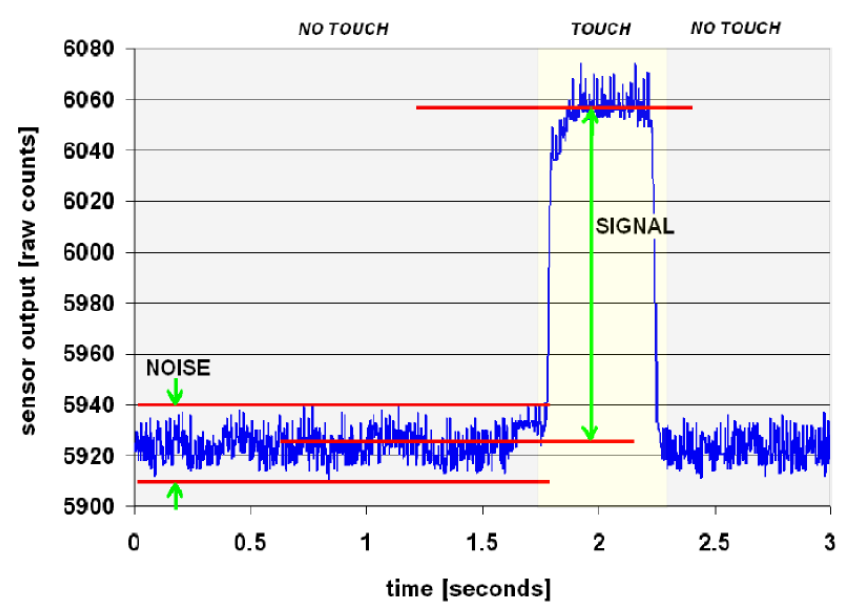

Fig. 3. The process of filtering and correction of signals

and correct the signals received from the electronic control instrument and to visualize the test results. When the exercise is completed, the result is displayed on the screen, which is then stored in the integrated test control database. This database facilitates their replication, processing and interactive analysis using statistical and mathematical methods and algorithms. This is how we accumulate, update, correct, and multifaceted use of a large array of test data. Used interface provides a high level of ergonomic properties of the electronic control device and the ability of professionals to work effectively with the test data. Further archiving takes place in and accessible to each of the control entities in the storage and data center infrastructure in a personal text format. The application of the software allows simultaneous analysis of the results of testing of a group of control subjects without loss of information.

The main indicators that characterize the effectiveness of the use of the tool to control the development of the frequency of movements developed using ICT are:

- testing simplification and automation;

- ensuring accuracy, objectivity, reliability of test results;

- ease of use and compactness of the device: miniature, autonomy, compactness and portability;

- urgency of control, consisting of the time of receipt of information (usually within $60 \mathrm{~s}$ ), the time of viewing the received data and analysis of results;

- ensuring long-term follow-up during training sessions to update processing results;

- automatic retrieval of results of multiple tests, ease of viewing the structure of obtained results and their dynamics;

- rapid execution of complex calculations with the presentation of results in digital or graphical form;

- saving the results of the test control in the database in the format of hypertext arrays.

\section{Discussion}

The conducted research complements the available information that intensive development of scientific and technical process, strengthening its influence in modern science necessitates a significant improvement of the quality of scien- 
tific research (Armour, 2014; Asadi, Arazi, Young, \& Saez de Villarreal, 2016; Clarys, \& Cabri, 1993) and implementation of radical changes in the organization (Chow, Chung, Ma, Macfarlane, \& Shirley, 2017; Gonzalo-Skok, Sánchez-Sabaté, Izquierdo-Lupón, \& Sáez de Villarreal, 2019) and examination of the results of physical education (Kok, Komen, van Capelleveen, \& van der Kamp, 2020; Strohrmann, Harms, Kappeler-Setz, \& Troster, 2012).

We support scientific approaches to the need for effective physical education control to improve physical education (Alfrey, \& Gard, 2014; Bassett, 2000; Crocker, \& Algina, 2015), which is a complex and multifaceted task (Di Tore, Schiavo, D’isanto, 2016; Ivashchenko, 2016; Ivashchenko, \& Khudolii, 2016).

Our study supplements data on the unreliability of control information using valid test methods (Alfrey, \& Gard, 2014; Edwards, 2010; Koryahin, \& Blavt, 2019; Power, Handrigan, $\&$ Basset, 2012). We propose a new approach to the study of control in this area of knowledge. The novelty of the presented development is to harness the potential of modern ICT, which, given its prospects, is of particular interest to researchers today.

We coordinate the study according to the ideas of the need for retrofitting, updating, upgrading and intensification of test control in physical education (Clarys, \& Cabri, 1993; Capobianco, Almuklass, \& Enoka, 2018). We support scientific approaches to the implementation and use of modern ICT in this process, which will help to solve the problems of test control (Chow, Chung, Ma, Macfarlane, \& Shirley, 2017; Koryahin, Blavt, \& Ponomaryov, 2019).

According to the results of the research, scientific ideas on operational control of physical qualities in real time with the use of ICT have been further developed (Estivalet, \& Springer, 2009; Hotra, Mahlovanyy, Mykytyuk, Ivakh, \& Politanskyi, 2019; Koryahin, Mukan, Blavt, \& Virt, 2019). Utilizing the potential of modernization in today's scientific space, it is possible to significantly enhance the informatization of physical fitness through the use of ICT (Koryahin, \& Blavt, 2018; Preatoni, Hamill, Harrison, Hayes, Van Emmerik, Wilson, \& Rodano, 2013; Shepard, \& Janky, 2008).

\section{Conclusions}

The urgent need to integrate all fields of knowledge into the world of educational space requires a major modernization of the content of the theory and methodology of physical education. After all, the modern system should reflect the movement towards the information society, undergo continuous improvement due to the use of own advanced ideas of intensive use of modern ICT tools by domestic researchers.

Introduced electronic device for performing the test of the frequency of hand movements, developed using modern electronic technologies and software, is proposed for the first time and has significant advantages over the existing method of testing the quality of speed. The use of in-house development ensures that objective, reliable test results are obtained promptly.

The use of ICT capabilities as a tool for solving control tasks based on the modernization of this process, provides a qualitatively new technological advance in the methods and didactics, organization and practical implementation of speed control in physical education.
The main methodological result of the study is that the use of the proposed electronic test device to control the frequency of movements of the hands allows to intensify the testing process during physical education. In turn, it allows to solve in a comprehensive manner the issues of timely introduction of adjustments to the training program in accordance with the obtained results.

\section{Conflict of interest}

The authors state no conflict of interest.

\section{References}

Armour, K. (2014). New Directions for Research in Physical Education and Sport Pedagogy. Sport, Education and Society, 19(7), 853-854. https://doi.org/10.1080/13573322.2014.899493

Alfrey, L., \& Gard, M. (2014). A crack where the light gets in: a study of Health and Physical Education teachers' perspectives on fitness testing as a context for learning about health. Asia-Pacific Journal of Health, Sport and Physical Education, 5(1), 3-18. https://doi.org/10.1080/18377122.2014.867790

Alme, K.J., \& Mylvaganam, S. (2006). Electrical Capacitance Tomography: Sensor Models, Design, Simulations, and Experimental Verification IEEE. Sensors Journal, 6(5), 1256-1266. https://doi.org/10.1109/JSEN.2006.881409

Asadi, A., Arazi, H., Young, W.B., \& Saez de Villarreal, E. (2016). The effects of plyometric training on change-ofdirection ability: A meta-analysis. International Journal of Sports Physiology and Performance, 11(5), 563-573. https://doi.org/10.1123/ijspp.2015-0694

Bassett, D.R. (2000). Validity and reliability issues in objective monitoring of physical activity. Research Quarterly for Exercise and Sport, 71, 30-36. https://doi.org/10.1080/02701367.2000.11082783

Bracke, W., Puers, R., \& Van Hoof, C. (2007). Ultra low power capacitive sensor interfaces. Springer.

Capobianco, R.A., Almuklass, A.M. \& Enoka, R.M. (2018). Manipulation of sensory input can improve stretching outcomes. European Journal of Sport Science, 18(1), 83-91. https://doi.org/10.1080/17461391.2017.1394370

CapSenseTM. Best practices notebook, Cypress (2006). http://www.cyprees.com

Chow, G.C.C., Chung, J.W.Y., Ma A.W.W, Macfarlane, D.J., \& Shirley, S.M.F. (2017). Sensory organisation and reactive balance control of amateur rugby players: A crosssectional study. European Journal of Sport Science, 17(4), 400-406. https://doi.org/10.1080/17461391.2016.1257656

Clarys, J.P., \& Cabri, J. (1993). Electromyography and the study of sports movements: A review. Journal of Sports Sciences, 11(5), 379-448. https://doi.org/10.1080/02640419308730010

Crocker, L., \& Algina, J. (2015). Introduction to Classical and Modern Test Theory. New-York: Harcourt Brace Jovanovich.

Di Tore, P. A., Schiavo, R., \& D’isanto, T. (2016). Physical education, motor control and motor learning: theoretical paradigms and teaching practices from kindergarten 
to high school. Journal of Physical Education and Sport, 16(4), 1293-1297.

https://doi.org/10.7752/jpes.2016.04205

Geoffrey, A., Power, G., Handrigan, A., \& Basset, F.A. (2012). Ventilatory response during an incremental exercise test: A mode of testing effect. Pedagogy, 12(6): 491-498. https://doi.org/10.1080/17461391.2011.573580

Gonzalo-Skok, O., Sánchez-Sabaté, J., Izquierdo-Lupón, L. \& Sáez de Villarreal, E. (2019). Influence of force-vector and force application plyometric training in young elite basketball players. European Journal of Sport Science, 19(3), 305-314.

https://doi.org/10.1080/17461391.2018.1502357

Gonzalo-Skok, O., Serna, J., Rhea, M.R., \& Marin, P.J. (2015). Relationships between functional movement tests and performance tests in young elite male basketball players. International Journal of Sports Physical Therapy, 10(5), 628-638.

Gonzalo-Skok, O., Tous-Fajardo, J., Suarez-Arrones, L., ArjolSerrano, J.L., Casajus, J.A., \& Mendez-Villanueva, A. (2015). Validity of the V-cut test for young basketball players. International Journal of Sports Medicine, 36(11), 893-899. https://doi.org/10.1055/s-0035-1554635

Edwards, W.H. (2010). Motor Learning and Control From Theory to Practice. California: Wadsworth.

Estivalet, M., \& Springer, P. (2009). The Engineering of Sport. Paris: Springer-Verlag.

Jrgensen, T., Andersen, L.B., Froberg, K., Maeder, U.L., Smith, von H. \& Aadahl, M. (2009). Position statement: Testing physical condition in a population - how good are the methods? European Journal of Sport Science, 9(5), 257-267. https://doi.org/10.1080/17461390902862664

Haake, S. (1996). The engineering of sport. Taylor \& Francis.

Hardman, K, \& Green, K. (2011). Contemporari issues in phisical education. Mayer \& Mayer Verlag.

Hotra, Z, Mahlovanyy, A, Mykytyuk, Z, Ivakh, M, \& Politanskyi, R. (2019). Schematic Realization of Flexible Algorithm in Treatment Diagnostic Devices. IEEE XVth International Conference on the Perspective Technologies and Methods in MEMS Design. https://doi.org/10.1109/MEMSTECH.2019.8817378

Hotra, Z., Mykytyuk, Z., Sushynskyy, O., Hotra, O., Yasynovska, O., \& Kisała, P. (2010). Sensor systems with optical channel of information transferring. Przeglad Elektrotechniczny, 86(10), 21-23.

Ivashchenko, O.V. (2016). Pedagogical control of motor and functional fitness of girls 15-16 years. Teoriâ ta Metodika Fizičnogo Vihovannâ, (3), 36-50.

https://doi.org/10.17309/tmfv.2016.3.1171 (in Ukrainian).

Ivashchenko, O. \& Khudolii, O. (2016). Methodological approaches to pedagogical control in the process of physical education of girls 12-14 years old. Teoriâ ta Metodika Fizičnogo Vihovannâ, (4), 13-24. https://doi.org/10.17309/tmfv.2016.4.1175 (in Ukrainian).

Kok, M., Komen, A., L. van Capelleveen, \& J. van der Kamp. (2020). The effects of self-controlled video feedback on motor learning and self-efficacy in a Physical Education setting: an exploratory study on the shot-put. Physical Education and Sport Pedagogy, 25(1), 49-66. https://doi.org/10.1080/17408989.2019.1688773
Koryagin, V., \& Blavt, O. (2019). Innovative test control technologies in physical education and sports: a monograph. Lviv, Ukraine: Lviv Polytechnic Publishing House, 236.

Koryahin, V., \& Blavt, O. (2018). The Use of Information and Communication Technology for Determining the Level Mobility in Joint in Physical Education of Students. Teori $\hat{a}$ ta Metodika Fizičnogo Vihovannâ, 18(3), 107-113. https://doi.org/10.17309/tmfv.2018.3.01

Koryahin, V., Blavt, O., \& Ponomaryov, S. (2019). Innovative Intestification of Testing of Strength Endurance in Physical Education of Students With Chronic Diseases. Teoriâ ta Metodika Fizičnogo Vihovannâ, 19(3), 116-122. https://doi.org/10.17309/tmfv.2019.3.02

Koryahin, V., Mukan, N., Blavt, O., \& Virt, V. (2019). Students' coordination skills testing in physical education: ICT application. Information Technologies and Learning Tools, 70(2), 216-226. https://doi.org/10.33407/itlt.v70i2

Lauber, B., \& Keller, M. (2014). Improving motor performance: Selected aspects of augmented feedback in exercise and health. European Journal of Sport Science, 14(1), 36-43. https://doi.org/10.1080/17461391.2012.725104

Magill, R.A. (2007). Motor learning and control: Concepts and applications (8th ed.). McGraw-Hill International Edition.

Malaric, R. (2011). Instrumentation and Measurement in Electrical Engineering. BrownWalker Press. Boca Raton, Florida. USA.

Matiegka, J. (1991). The testing of physical efficiency. Amer. Journal of Physical Anthropology, 4(3), 125-134. https://doi.org/10.1002/ajpa.1330040302

Mitchell, L.J.G., Pyne, D.B., Saunders, P.U. \& Rattray, B. (2018). Reliability and validity of a modified 3-minute all-out swimming test in elite swimmers. European Journal of Sport Science, 18(3). https://doi.org/10.1080/17461391.2017.1413138

Mykytyuk, Z., Fechan, A., Shymchyshyn, O., Rudyi, A., Nazarenko, V., \& Petryshak, V. (2012). Sensor network based on gas smart sensors for environmental monitoring. In Modern Problems of Radio Engineering, Telecommunications and Computer Science - Proceedings of the 11th International Conference, TCSET'2012, 503-504.

Reiman, M.P., \& Manske, R.C. (2009). Functional testing in human performance. Champaign IL : Human Kinetics.

Preatoni, E., Hamill, J., Harrison, A.J., Hayes, K., Van Emmerik, R., Wilson, C. \& Rodano, R. (2013). Movementvariability and skills monitoring in sports. Sports Biomechanics, 12(2), 69-92. https://doi.org/10.1080/14763141.2012.738700

Power, G.A., Handrigan, G.A. \& Basset, F.A. (2012). Ventilatory response during an incremental exercise test: A mode of testing effect. European Journal of Sport Science, 12(6), 491-498. https://doi.org/10.1080/17461391.2011.573580

Schmidt, R.A., \& Wrisberg, C.A. (2008). Motor Learning and Performance: A Situation-based Learning Approach. (I. Champaign, Ed.). Human Kinetics.

Silverman, S., Keating, X.D., \& Phillips, S.R. (2008). A lasting impression: A pedagogical perspective on youth fitness testing. Measurement in Physical Education and Exercise Science, 12, 146-166. https://doi.org/10.1080/10913670802216122

Shepard, N.T., \& Janky, K. (2008). Background and technique of computerized dynamic posturography. San Diego, CA: Plural. 
Starling, L.T., Nellemann, S., Parkes, A. \& Lambert, M.I. (2020). The Fatigue and Fitness Test for Teams (FFITT): A practical option for monitoring athletes in a team as individuals. European Journal of Sport Science, 20(1), 106114. https://doi.org/10.1080/17461391.2019.1612951

Stroot, S.A. (2014). Case Studies in Physical Education: Real World Preparation for Teaching. Routledge, 156.

Strohrmann, C., Harms, H., Kappeler-Setz, C., \& Troster, G. (2012). Monitoring kinematic changes with fatigue in running using body-worn sensors. IEEE Transactions on Information Technology in Biomedicine, 16(5), 983-990. https://doi.org/10.1109 / TITB.2012.2201950
Olmos, A. M., Primicia, A. J., \& Fernandez Marron, J. L. (2007) Simulation design of electrical capacitance tomography sensors. IET Science, Measurement \& Technology, 1(4), 216-223. https://doi.org/10.1049/iet-smt:20060108

Thomas, J.R, Nelson, J.K, \& Silverman, S.J. (2015). Research methods in physical activity, 7th ed. Champaign: Human Kinetics.

Wulf, G. \& Lewthwaite, R. (2009). Conceptions of Ability Affect Motor Learning. Journal of Motor Behavior, 41(5), 461467. https://doi.org/10.3200/35-08-083

\title{
ДИДАКТИЧНІ МОЖЛИВОСТІ ІНФОРМАЦІЙНО-КОМУНІКАТИВНИХ ТЕХНОЛОГІЙ У КОНТРОЛІ ФІЗИЧНОГО ВИХОВАННЯ
}

\author{
Віктор Корягін $^{\mathrm{ABCD}}$, Зіновій Микитюк ${ }^{\mathrm{ABCD}}$, Оксана Блавт $^{\mathrm{ABCD}}$, Любов Дольникова ${ }^{\mathrm{ABCD}}$, \\ Володимир Стадник ${ }^{\mathrm{ABCD}}$ \\ Національний університет «Львівська політехніка»
}

Авторський вклад: А - дизайн дослідження; В - збір даних; C - статаналіз; D - підготовка рукопису; Е - збір коштів

Реферат. Стаття: 7 с., 3 рис., 48 джерел.

Мета дослідження - обгрунтування та реалізація інформаційно-комунікативних технологій у тестовому контролі рівня розвитку частоти рухів, як прояву швидкісних якостей в процесі фізичного виховання.

Матеріали та методи. Представлено методи, використані у дослідженні, серед яких теоретичний аналіз наукової літератури, аналіз і синтез, індукція та дедукція, співставлення, порівняння та рефлексія, метод систематизації та узагальнення. Для вирішення дослідницьких завдань використано методи технічного моделювання.

Результати. Для реалізації мети дослідження розроблено електронний пристрій контролю виконання тестової вправи: частоти рухів рук для оцінки швидкісних якостей. Пристрій сконструйований на основі сенсорів наближення ємнісного типу. Сигнал, отриманий сенсорами, при вико- нанні тесту обробляють у блоці мікроконтролера та через інтерфейс зв'язку, передають на персональний комп'ютер. У персональному комп'ютері з використанням розробленого програмного забезпечення реалізують контроль часу виконання тестового завдання.

Висновки. Електронний пристрій, розроблений на основі інформаційно-комунікативних технологій, втілює новий підхід до вирішення проблеми підвищення ефективності контролю швидкісних якостей у фізичному вихованні та забезпечує термінове отримання об'єктивних та надійних даних тестування.

Ключові слова: фізичне виховання, тестування, контроль, інформаційно-комунікативні технології, частота рухів, швидкісні якості, пристрій.

\section{Information about the authors:}

Koryahin Viktor: koryahinv@meta.ua; https://orcid.org/0000-0003-1472-4846; Lviv Polytechnic National University, Bandera, St, 12, Lviv, 79013, Ukraine.

Mykytyuk Zinovy: zm.mykytiuk@gmail.com; https://orcid.org/0000-0002-1944-2015; Lviv Polytechnic National University, Bandera, St, 12, Lviv, 79013, Ukraine

Blavt Oksana: oksanablavt@ukr.net; https://orcid.org/0000-0001-5526-9339; Lviv Polytechnic National University, Bandera St, 12, Lviv, 79013, Ukraine.

Dolnikova Liubov: dolnikova.lubov@ukr.net; http://orcid.org/0000-0003-0719-2028; Lviv Polytechnic National University, Bandera, St, 12, Lviv, 79013, Ukraine.

Stadnyk Volodymyr: vova121212131313@ukr.net; https://orcid.org/0000-0002-2864-4794; Lviv Polytechnic National University, Bandera St, 12, Lviv, 79013, Ukraine.

Cite this article as: Koryahin, V., Mykytyuk, Z., Blavt, O., Dolnikova, L., \& Stadnyk, V. (2020). Didactic Opportunities of Information-Communication Technologies in the Control of Physical Education. Teoriâ ta Metodika Fizičnogo Vihovannâ, 20(2), 102-108. https://doi.org/10.17309/tmfv.2020.2.06

Received: 17.04.2020. Accepted: 20.06.2020. Published: 25.06.2020

This work is licensed under a Creative Commons Attribution 4.0 International License

(http://creativecommons.org/licenses/by/4.0). 